\title{
Analisis Spektrum Gelombang di Perairan Pulau Panjang
}

\author{
Mizan Zikrullah Abdulkadir ${ }^{*}$, Indra Budi Prasetyawan ${ }^{1}$, Denny Nugroho Sugianto ${ }^{1}$, Agus Anugroho \\ Dwi Suryoputro ${ }^{1}$, Heriyoso Setyono ${ }^{1}$, Petrus Subardjo ${ }^{1}$
}

\author{
${ }^{1}$ Departemen Oseanografi, Fakultas Perikanan dan Ilmu Kelautan, Universitas Diponegoro \\ J1. Prof. H. Sudarto, SH, Tembalang Semarang. 50275 Telp/fax (024)7474698 \\ Email corresponding author: aemizan17@gmail.com
}

\begin{abstract}
Abstrak
Pulau Panjang merupakan salah satu pulau yang dikategorikan sebagai pulau kecil dan terdapat di Kelurahan Ujungbatu, Kecamatan Jepara, Kabupaten Jepara, Provinsi Jawa Tengah. Masalah yang dihadapi Pulau Panjang adalah erosi yang semakin menggerus bibir pantai dan mulai merusak bangunan yang berada di pinggir pantai. Tujuan dilakukannya penelitian ini adalah untuk mengetahui spektrum gelombang dan karakteristik gelombang di Perairan Pulau Panjang, Jepara, Jawa Tengah. Metode yang digunakan dalam penelitian ini bersifat kuantitatif. Software yang digunakan dalam penelitian ini adalah Surface Water Modelling System (SMS) dengan modul STWAVE. Hasil pengolahan data lapangan menunjukkan bahwa tinggi gelombang maksimum adalah sebesar 0,435 meter dengan periode 6,5 detik. Tinggi gelombang signifikan (Hs) 0,219 meter dengan periode gelombang signifikan (Ts) 3,1 detik. Hasil pemodelan spektrum gelombang menunjukkan bahwa nilai energi gelombang berbanding lurus dengan nilai tinggi gelombangnya.
\end{abstract}

Kata Kunci: Gelombang, Karakteristik Gelombang, Spektrum Gelombang, Perairan Pulau Panjang Jepara

\section{Abstract}

Pulau Panjang is one of the islands which is categorized as a small island and is located in Ujungbatu Village, Jepara District, Jepara Regency, Central Java Province. The problem faced by Panjang Island is erosion which increasingly erodes the shoreline and begins to damage buildings on the beach. The purpose of this study is to knowing the wave spectrum and characteristic of waves at Panjang Island, Jepara. The research was conducted on 7 March - 11 March 2019 at Panjang Island Waters. The methods used in this study were quantitative methods. The software used in this study is the Surface Water Modelling System (SMS) with STWAVE module. The result of the field data shows that the maximum wave height was 0,435 meters with a period of 6,5 seconds. Significant wave height (Hs) was 0,219 meters with a significant wave period (Ts) of 3,1 seconds. Based on the result of wave spectrum models it can be concluded that the wave energy value have linear condition with the wave height value.

Keywords: Waves, Waves Characteristic, Wave Spectrum, Pulau Panjang Waters

\section{PENDAHULUAN}

Abrasi merupakan salah satu masalah yang mengancam kondisi pesisir dan akibatnya garis pantai beralih lebih ke belakang dari posisinya semula. Masalah abrasi pantai cenderung meningkat di berbagai daerah di Indonesia, termasuk pantai-pantai di Kabupaten Jepara salah satunya di pantai Pulau Panjang. Faktor alam berpengaruh terhadap Pulau Panjang yakni dengan gelombang yang tinggi akan menyebabkan abrasi pantai. Faktor lain yang menyebabkan abrasi adalah akibat hempasan gelombang laut yang berasal dari jalur pelayaran kapal-kapal cepat yang menuju Pulau Karimunjawa, tepatnya di timur Pulau Panjang (Malik, 2017).

Faktor penting abrasi pantai adalah gelombang laut selain arus dan pasang surut. Sehingga informasi mengenai parameter gelombang laut seperti tinggi dan periode gelombang serta spektrum energinya merupakan hal penting yang perlu diperhatikan oleh masyarakat pesisir. Parameter-parameter ini diperlukan untuk pengembangan potensi wilayah pesisir secara optimal khususnya dalam perencanaan bangunan pantai dan lepas pantai serta untuk penentuan dan pertimbangan alur pelayaran. Informasi tentang parameter 
gelombang yang merupakan karakteristik gelombang di perairan Indonesia saat ini masih kurang, hal ini disebabkan mahalnya biaya operasional pengumpulan data actual serta masih kurangnya penelitian di bidang ini yang pernah dilakukan. Cara lain yang lebih murah adalah melalui simulasi model numerik gelombang laut

Perkiraan dari kondisi gelombang laut secara visual umumnya dapat dilihat melalui gelombang tertinggi dalam medan gelombang lautnya. Pada tinggi dan periode gelombang signifikan ternyata memiliki kelemahan, yaitu tidak dapat menjelaskan secara spesifik keadaan permukaan laut pada saat bercampurnya permukaan pada gelombang sea yang dipengaruhi angin dan gelombang swell yang memiliki tinggi signifikan, periode signifikan, dan arah yang sama. Hal ini dapat diatasi dengan cara memisahkan tinggi dan periode gelombang signifikan untuk kondisi gelombang sea dan swell dengan menggunakan pendekatan metode spektrum (Holthuijsen, 1989).

Spektrum gelombang merupakan representatif dari jumlah energi gelombang yang terjadi pada masing-masing variasi frekuensi gelombang. Bentuk dari spektrum gelombang sangat bervariasi tergantung pada tinggi gelombang, periode yang dibutuhkan, dan kecepatan angin (Brillin et al., 2015). Analisis spektrum merupakan metode yang digunakan untuk mengestimasi fungsi densitas spektral dari sebuah deret waktu. Analisis spektrum dapat digunakan sebagai alat untuk menganalisis data yang berkaitan dengan masalah fenomena selain topografi yang berhubungan dengan waktu, yang tentunya diperlukan suatu teknik tersendiri dalam mengurai informasi data (Satriyani, 2007).

\section{MATERI DAN METODE}

\section{Materi Penelitian}

Materi yang digunakan pada penelitian ini meliputi data utama yaitu pengukuran gelombang lapangan di Perairan Pulau Panjang, Jepara. Data penunjang berfungsi sebagai pendukung data utama yang meliputi data angin harian selama 11 tahun (tahun 2009-2019) dari website Ogimet serta data batimetri hasil survey di lokasi penelitian.

\section{Metode Penelitian}

Metode penelitian yang digunakan pada penelitian ini adalah dengan metode kuantitatif, karena data penelitian yang digunakan berupa angka-angka dan dianalisis (Sugiyono, 2009). Data angin yang didapat diolah yang kemudian diramalkan dengan Metode Sugianto (2017), sehingga mendapatkan hasil tinggi dan periode gelombang signifikan. Data tinggi dan periode gelombang tersebut kemudian digunakan dalan pemodelan penjalaran gelombang serta spektrum gelombang

\section{Metode Penentuan Lokasi}

Lokasi pengukuran gelombang di Perairan Pulau Panjang tersebut ditentukan dengan pertimbangan bebas halangan, sehingga gelombang yang terbentuk tidak terhalang hambatan. Penempatan alat tersebut harus dengan pertimbangan faktor keamanan alat dan kemudahan aksesnya, serta pertimbangan bahwa stasiun pengukuran mewakili pergerakan gelombang di Perairan Pulau Panjang, Kab. Jepara, Jawa Tengah 


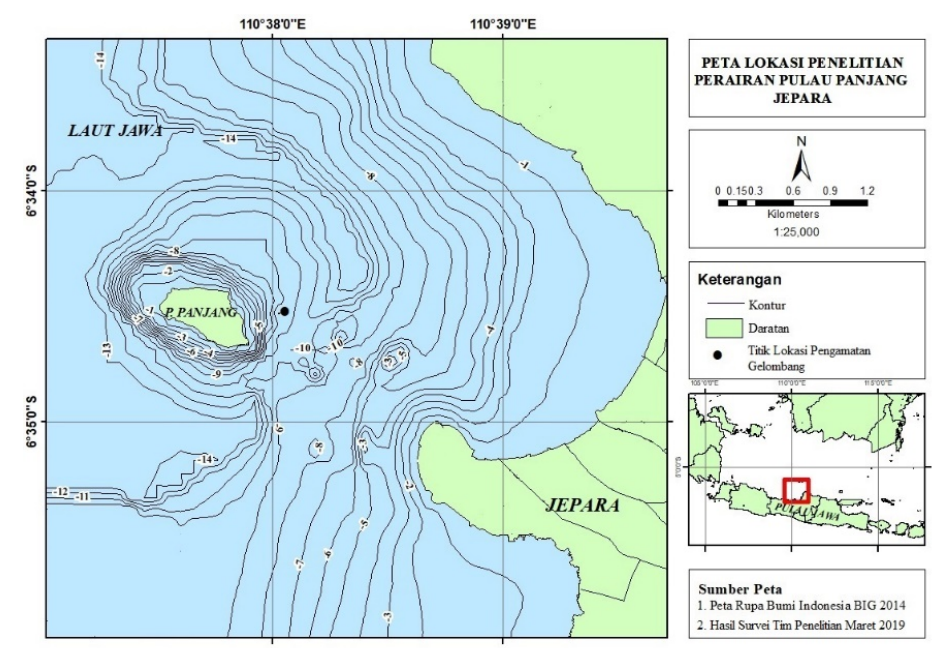

Gambar 1. Peta Lokasi Penelitian

\section{Metode Pengambilan Data}

Pengamatan dan pengambilan data gelombang dengan menggunakan ADCP SonTek Argonaut -XR pada kedalaman 10 meter di Perairan Pulau Panjang, Kab. Jepara untuk mendapatkan parameter gelombang seperti tinggi gelombang $(\mathrm{H})$ dan periode gelombang $(\mathrm{T})$ selama 5 hari. Cara kerja ADCP yaitu dengan merekam menggunakan sistem sensor penjalaran tekanan dan dapat diatur untuk mengumpulkan dan merekam elevasi gelombang dalam arah $\mathrm{x}$ dan y dengan mengirimkan gelombang suara dengan frekuensi tertentu dan menentukan kembalinya hamburan sinyal perpindahan frekuensi dari pantulan partikel kecil yang ada dalam air.

Data angin diperoleh dengan observasi tidak langsung, data tersebut didapatkan dengan cara mengunduh dari website Ogimet. Data tersebut meliputi arah dan kecepatan angin, data yang diperlukan adalah data angina per 3 jam selama 11 tahun periode Maret 2009 hingga Maret 2019.

\section{Metode Pengolahan dan Analisis Data}

Data angin yang digunakan dalam penelitian ini adalah data angin selama 11 tahun (2009-2019). Data angin 11 tahun tersebut dianalisis menggunakan software pembuat mawar angin (wind rose) untuk mengetahui kondisi hembusan angin dominan setiap musim di daerah penelitian. Data angin selama 11 tahun yang telah disortir selanjutnya digunakan sebagai data untuk peramalan gelombang.

Data parameter gelombang pengukuran lapangan yang meliputi data tinggi $(\mathrm{H})$ dan periode gelombang (T) dianalisa dengan metode gelombang representatif, yaitu metode yang dapat mewakili karakteristik keseluruhan data gelombang. Metode tersebut meliputi:

1. Data tinggi gelombang dan periode gelombang diurutkan dari data yang tertinggi sampai data yang terendah.

2. Kemudian mencari nilai tinggi gelombang signifikan (Hs) dan periode gelombang signifikan (Ts):

$\mathrm{n}=33,3 \% \mathrm{x}$ jumlah data

$$
H S=\frac{H 1+H 2+\ldots+H n}{n}
$$

$$
\mathrm{Ts}=\frac{\mathrm{T} 1+\mathrm{T} 2+\ldots+\mathrm{Tn}}{n}
$$

Keterangan:

Hs $\quad$ : tinggi gelombang signifikan (m)

Ts : periode gelombang signifikan (detik)

$\mathrm{H}_{1}, \mathrm{Hn} \quad$ : tinggi gelombang ke $1,2, \ldots, \mathrm{n}(\mathrm{m})$ 
Peramalan gelombang yang terjadi di lokasi penelitian menggunakan data angin yang telah melalui proses filterisasi durasi dan kecepatan angin. Peramalan gelombang menggunakan Metode Sugianto. Perhitungan peramalan gelombang dilakukan dengan metode Sugianto yaitu melakukan distribusi kecepatan angin dimana kecepatan angin di atas 10 knot dapat digunakan sebagai perhitungan peramalan gelombang. Dalam menghitung tinggi signifikan (Hs) dan periode signifikan (Ts) digunakan rumus. Menurut Sugianto et al. (2017) langkah-langkah dalam peramalan gelombang metode Sugianto adalah sebagai berikut :

1. Data angin yang didapatkan dari website Ogimet disortir arah dan kecepatan anginnya

2. Masukkan persamaan metode Sugianto untuk mencari nilai Hs dan Ts

Rumus Hs :

$$
\mathrm{Hs}=0,0016 \times U^{2}+0,0406 U
$$

Rumus Ts :

$$
\mathrm{Ts}=0,15 U+2,892
$$

\section{Keterangan :}

$\begin{array}{ll}\mathrm{U} & \text { : kecepatan angin (knot) } \\ \mathrm{Hs} & \text { : gelombang signifikan } \\ \text { Ts } & \text { : periode gelombang signifikan }\end{array}$

3. Menentukan $\mathrm{H}$ maksimum, $\mathrm{H}$ minimum dan $\mathrm{H}$ rata-rata dan juga $\mathrm{T}$ maksimum, $\mathrm{T}$ minimum dan $\mathrm{T}$ rata-rata

4. Setelah itu sortir per-musim untuk meramalkan nilai Hs dan Ts permusim.

Data tinggi gelombang dan periode signifikan ini digunakan sebagai masukkan pada pemodelan gelombangnya. Simulasi model dilakukan dengan menggunakan perangkat lunak Surface Water Modelling System (SMS) dengan modul STeady State Spectral Wave (STWAVE) yang akan memberikan interpretasi dalam bentuk penjalaran dan spektrum gelombang.

\section{HASIL DAN PEMBAHASAN}

\section{Gelombang Lapangan}

Hasil dari pengukuran gelombang di lapangan pada titik koordinat $6^{\circ} 34^{\prime} 33,27 " \mathrm{~S}$ dan $110^{\circ} 38^{\prime} 23.08^{\prime \prime} \mathrm{E}$ dengan kedalaman 10 meter yang dilaksanakan pada tanggal 7-11 Maret 2019 di Perairan Pulau Panjang, Kabupaten Jepara, Jawa Tengah yang menghasilkan data gelombang sesuai pada Gambar 2 dan 3.

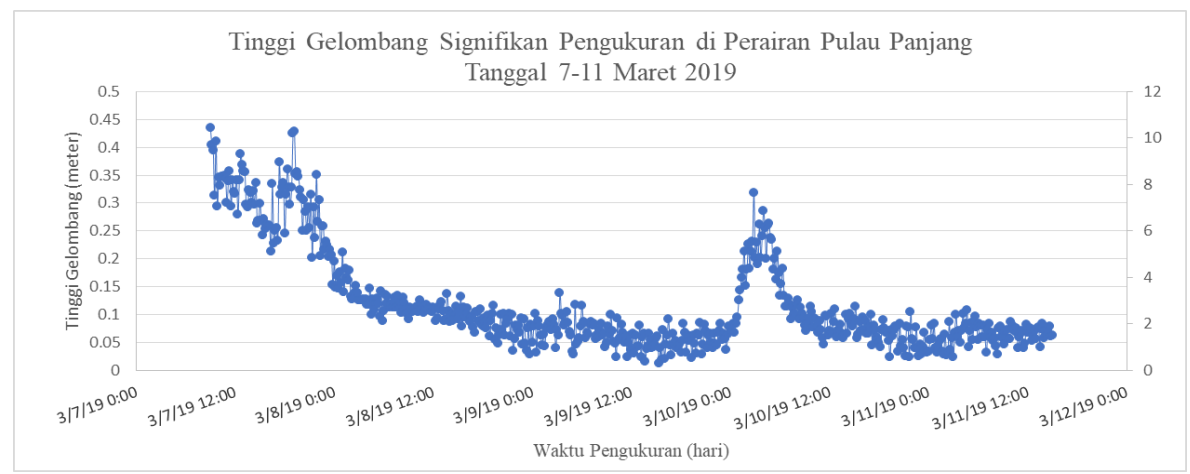

Gambar 2. Grafik Tinggi Gelombang Lapangan 


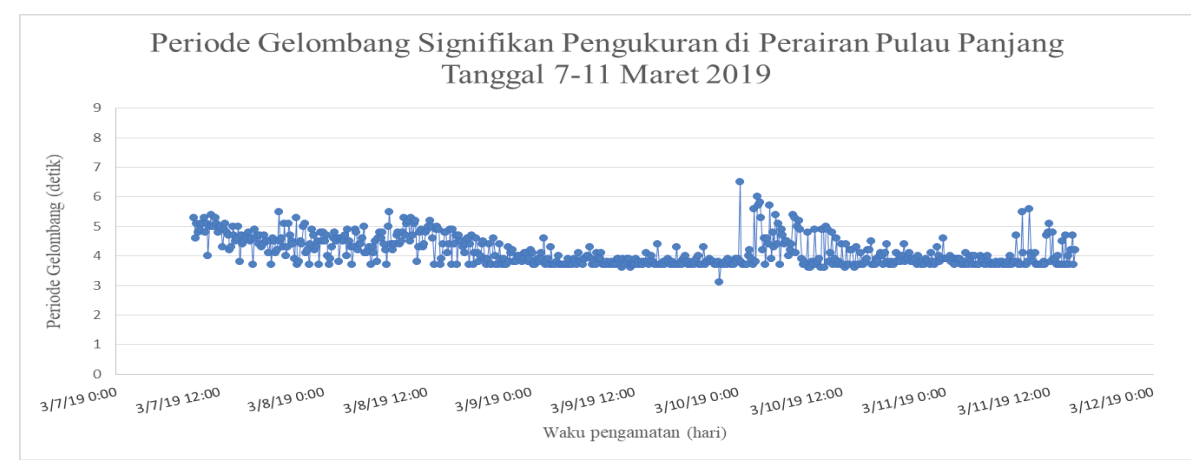

Gambar 3. Grafik Periode Gelombang Lapangan

Tabel 1. Tinggi dan Periode Gelombang Pengukuran Lapangan

\begin{tabular}{ccccccc}
\hline Tanggal & $\begin{array}{c}\text { Hs } \\
\text { Maksimum } \\
(\mathrm{m})\end{array}$ & $\begin{array}{c}\text { Hs } \\
\text { Rata-rata } \\
(\mathrm{m})\end{array}$ & $\begin{array}{c}\text { Hs } \\
\min (\mathrm{m})\end{array}$ & $\begin{array}{c}\text { Ts } \\
\text { max } \\
\text { (det) }\end{array}$ & $\begin{array}{c}\text { Ts } \\
\text { Rata-rata } \\
(\text { det })\end{array}$ & $\begin{array}{c}\text { Tmin } \\
(\text { det })\end{array}$ \\
\hline 7-11 Maret 2019 & 0,44 & 0,11 & 0,01 & 6,5 & 4,15 & 3,1 \\
\hline
\end{tabular}

\section{Konversi Data Angin}

Data angin yang digunakan dalam penelitia ini adalah data yang diunduh dari website Ogimet dengan menggunakan data angin selama 11 tahun dari Maret 2009 - Maret 2019. Data kecepatan dan arah angin tersebut disajikan dalam bentuk mawar angin. Berikut adalah arah angin hasil pengolahan data penunjang yang dikelompokkan secara musiman ditunjukkan pada Gambar 4.

Data angin dikonversi menjadi data tinggi gelombang $(\mathrm{H})$ dan periode gelombang $(\mathrm{T})$, selanjutnya dilakukan pengolahan data untuk mendapatkan nilai tinggi dan gelombang representatif yang dikelompokkan berdasarkan pembagian musim, yaitu musim barat, musim peralihan I, musim timur dan peralihan II yang dapat dilihat pada Tabel 2 .

Tabel 2. Tinggi dan Periode Peramalan Gelombang

\begin{tabular}{lcccccc}
\hline Musim & $\begin{array}{c}\text { Hs } \\
\mathbf{m a x} \\
(\mathbf{m})\end{array}$ & $\begin{array}{c}\text { Rata- } \\
\text { rata } \\
(\mathbf{m})\end{array}$ & $\begin{array}{c}\text { Hs } \\
\mathbf{m i n} \\
\mathbf{( m )}\end{array}$ & $\begin{array}{c}\text { Ts } \\
\text { Max } \\
\text { (det) }\end{array}$ & $\begin{array}{c}\text { Ts } \\
\text { Rata- } \\
\text { rata } \\
\text { (det) }\end{array}$ & $\begin{array}{c}\text { Ts } \\
\text { min } \\
\text { (det) }\end{array}$ \\
\hline Barat & 2,66 & 0,86 & 0,64 & 7,39 & 4,94 & 4,54 \\
Peralihan I & 2,26 & 0,77 & 0,64 & 6,94 & 4,78 & 4,54 \\
Timur & 2,13 & 0,75 & 0,64 & 6,79 & 4,74 & 4,54 \\
Peralihan II & 2,52 & 0,76 & 0,64 & 7,24 & 4,77 & 4,54 \\
\hline
\end{tabular}




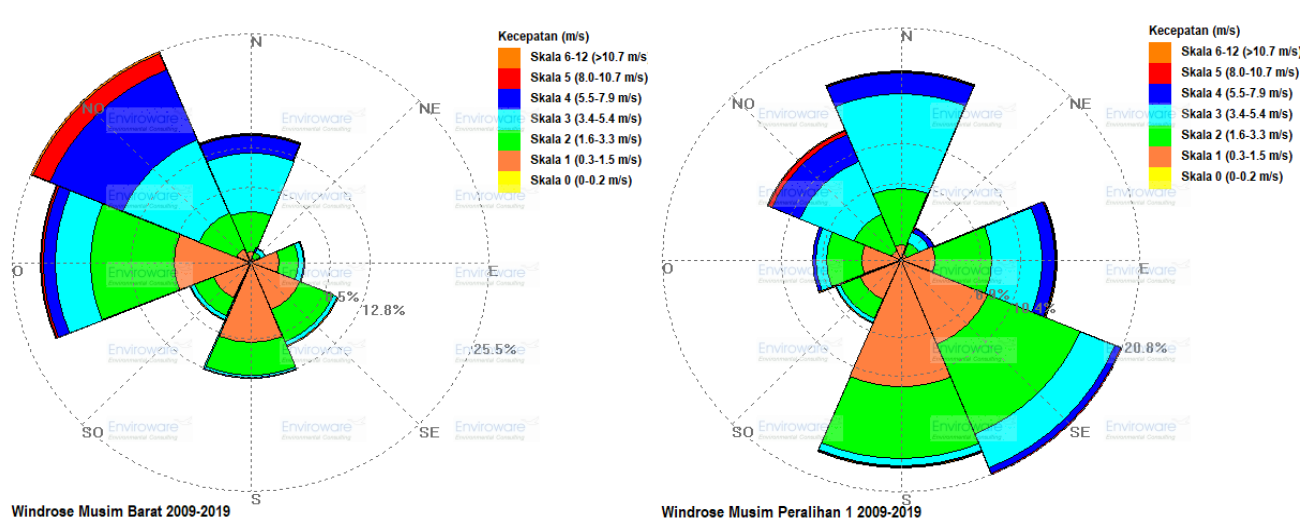

(a)

(b)

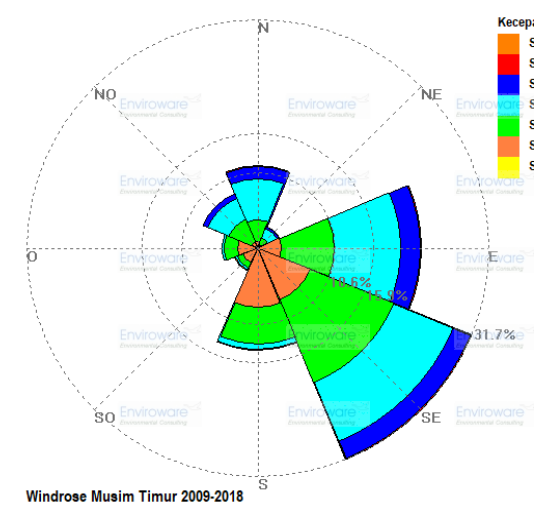

(c)

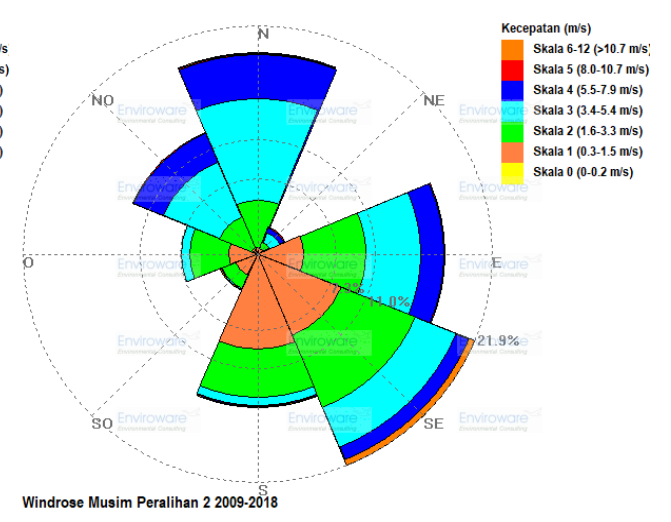

(d)

Gambar 4. Mawar Angin

(a) Musim Barat Tahun 2009 - 2019

(b) Musim Peralihan I Tahun 2009-2019

(c) Musim Timur Tahun $2009-2018$

(d) Musim Peralihan II Tahun $2009-2018$

\section{Pemodelan Spektrum Gelombang}

Pemodelan gelombang menggunakan software SMS modul STWAVE yang menghasilkan tinggi gelombang serta arah penjalarannya. Dalam pemodelan gelombang menggunakan inputan berbeda yang berdasarkan pembagian musim yaitu Musim Barat, Musim Peralihan I, Musim Timur dan Musim Peralihan II ditunjukkan pada Gambar 5. 

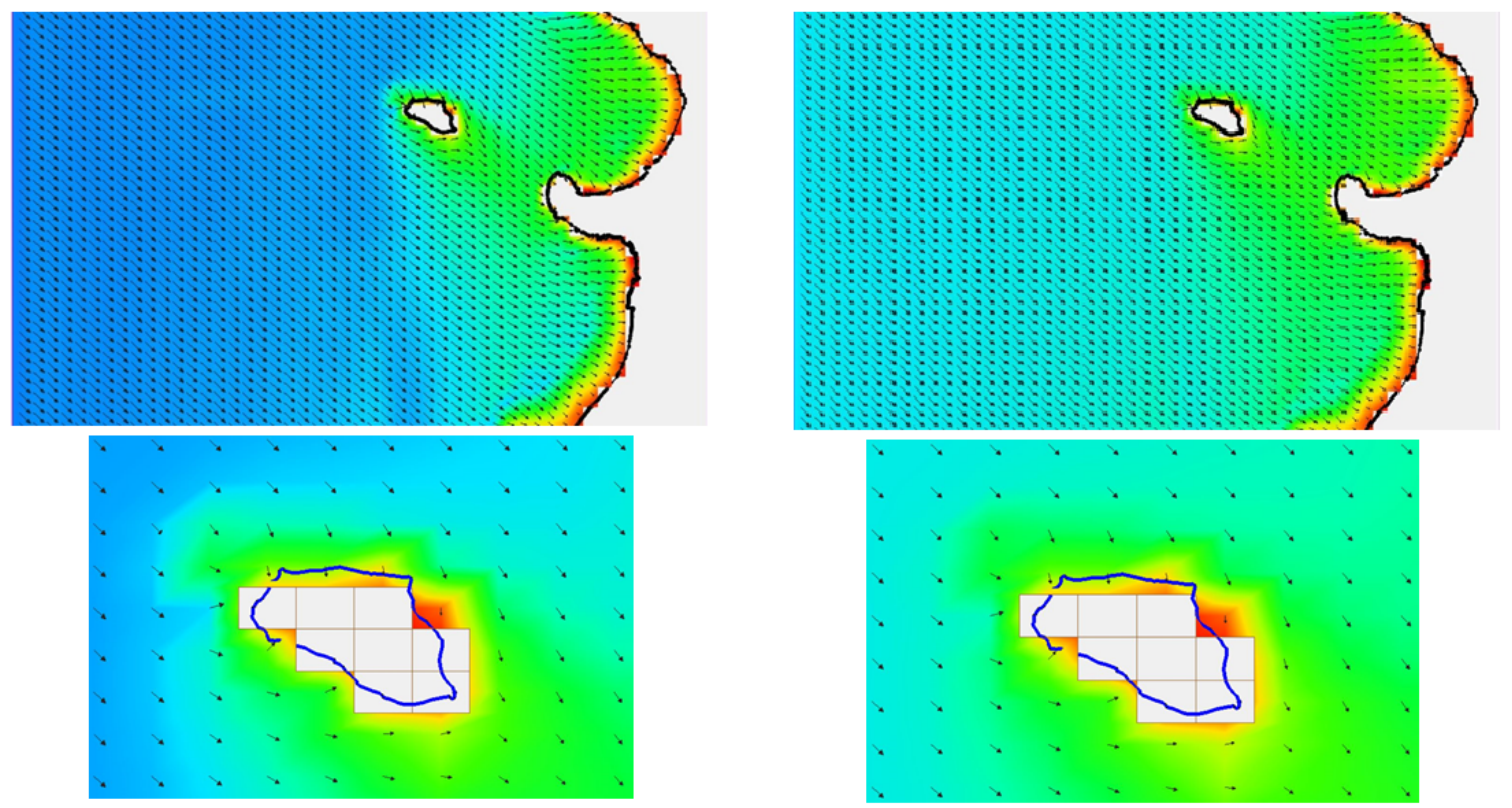

(a)

(b)
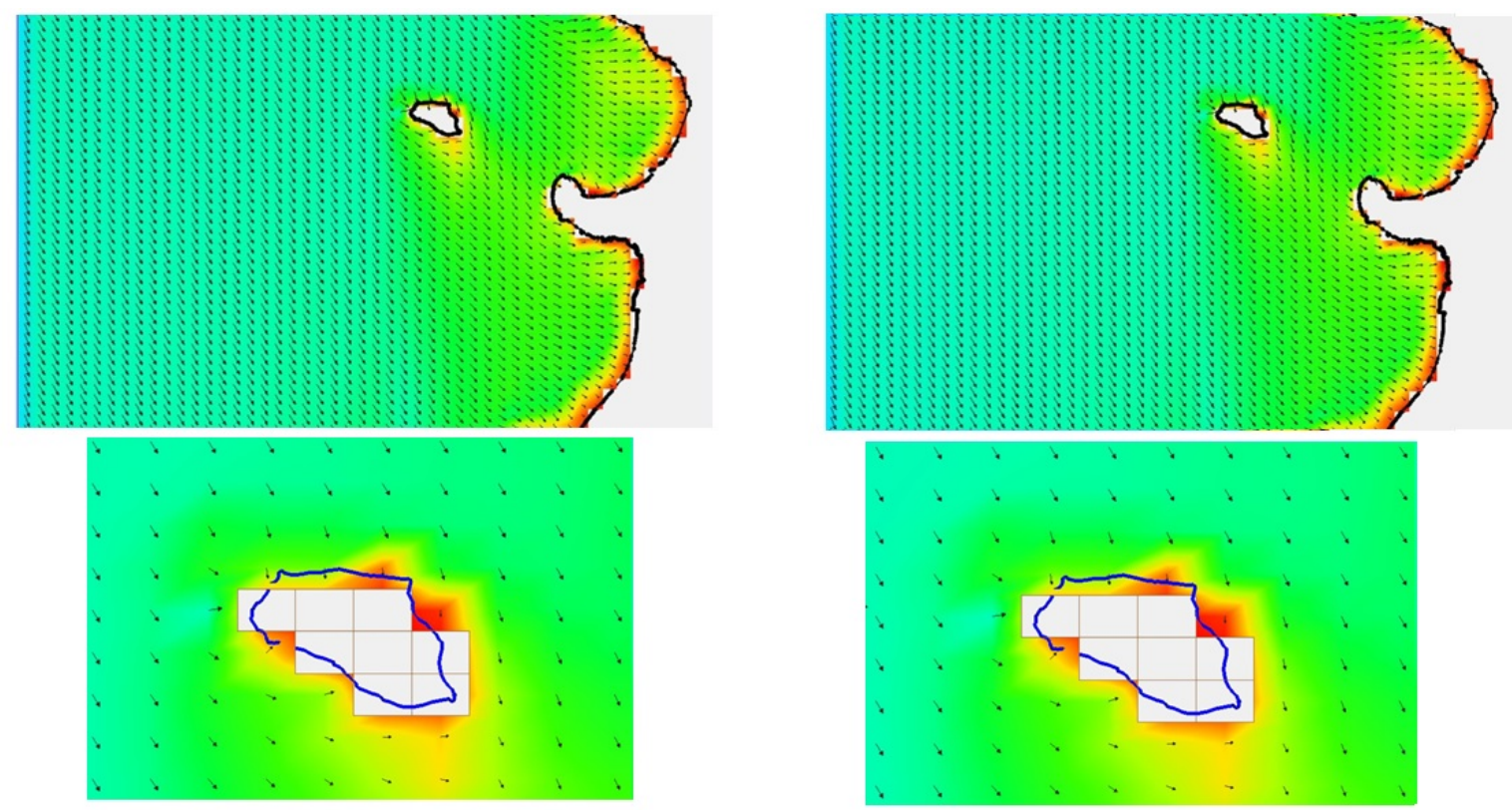

(c)

(d)

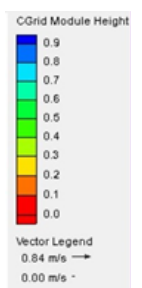

Gambar 5. Penjalaran Gelombang (a) Musim Barat (b) Musim Peralihan I (c) Musim Timur (d) Musim Peralihan II 
Spektrum gelombang digambarkan pada grafik spektrum polar 2D, dimana pada grafik tersebut dapat menjelaskan kondisi estimasi penjalaran gelombang. Grafik spektrum polar ini ditentukan dari nilai spektrum energinya, serta hubungannya antara arah serta frekuensi gelombang. Parameter yang ditinjau pada grafik spektrum polar 2D ini yaitu, frekuensi spektrum gelombang dan arah penjalaran energi gelombang. Grafik ini mempresentasikan kondisi penjalaran gelombang setiap musim pada daerah penelitian yang dapat diketahui pengaruhnya pada daerah tersebut. Grafik spektrum polar per musim dapat dilihat pada Gambar 5.
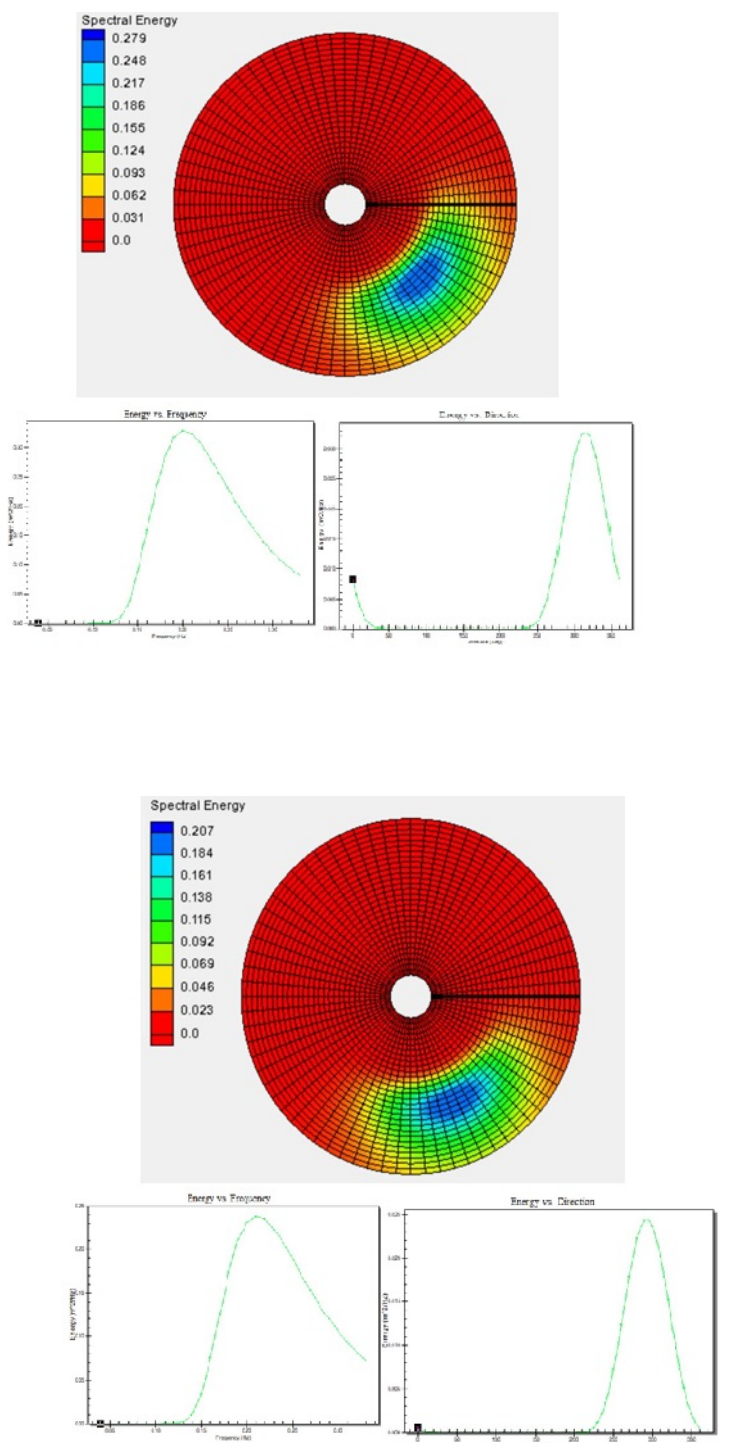

(c)

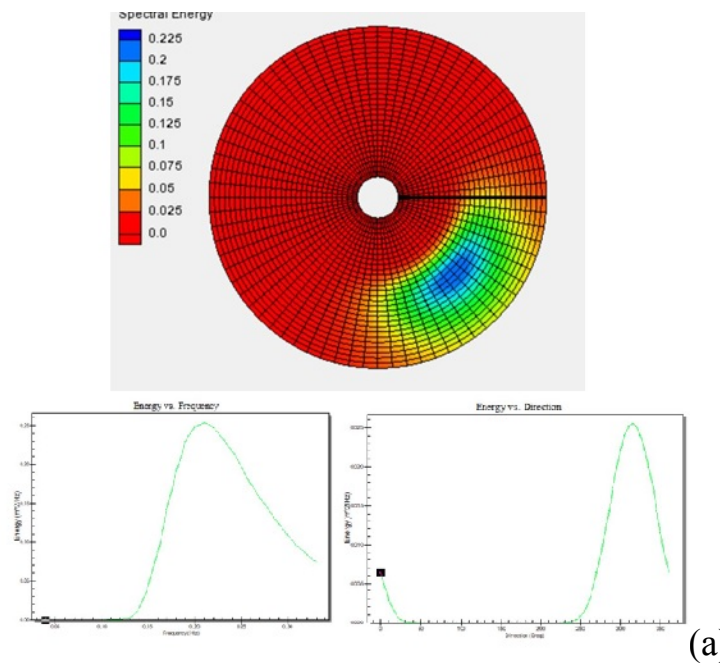

(b)

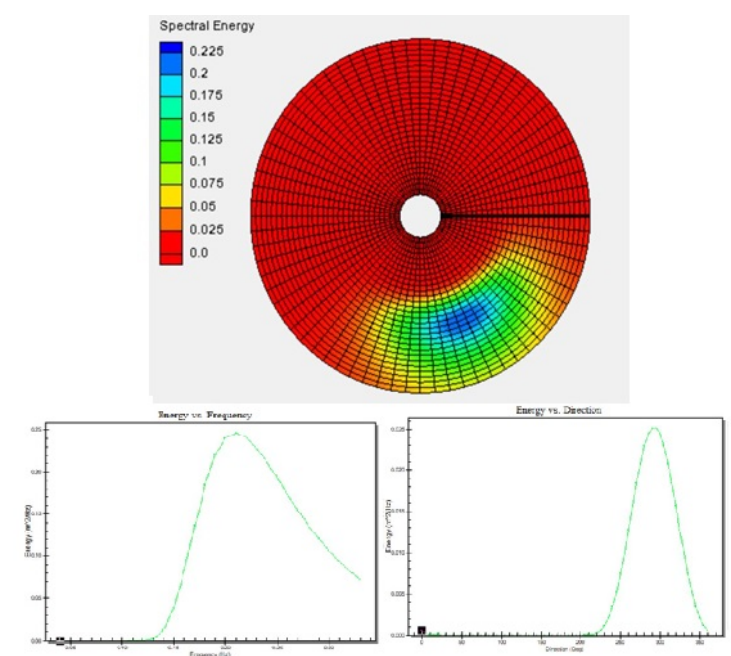

(d)

Gambar 6. Grafik Spektrum Gelombang (a) Musim Barat (b) Musim Peralihan 1 (c) Musim Timur (d) Musim Peralihan 2

Berdasarkan hasil pengukuran gelombang lapangan di Perairan Pulau Panjang, Kabupaten Jepara pada tanggal 7-11 Maret 2019 diperoleh hasil berupa tinggi gelombang maksimal (Hmaks) sebesar 0,44 m, tinggi gelombang signifikan $(\mathrm{Hs})$ sebesar 0,22 $\mathrm{m}$, dan tinggi gelombang minimum (Hmin) sebesar 0,012 $\mathrm{m}$. Sedangkan periode gelombang maksimum (Tmaks) sebesar 6,5 detik, periode gelombang signifikan (Ts) sebesar 4,54 detik, dan periode gelombang minimum (Tmin) sebesar 3,1 detik. 
Dapat dilihat dari hasil tersebut kecepatan relatif angin paling besar pada musim barat. Musim peralihan I, musim timur dan musim peralihan II arah dominannya berasal dari tenggara, sedangkan arah tenggara berasal dari daratan sehingga tidak digunakan dalam peramalan gelombang karena tidak dapat membangkitkan gelombang di laut.

Hasil tersebut menunjukkan nilai tinggi gelombang signifikan yang paling tinggi pada musim barat. Menurut Mulyadi et al (2015), pola angin pada musim barat terjadi karena posisi matahari berada di Bagian Bumi Selatan (BBS) khatulistiwa, yang menyebabkan Benua Australia bertekanan rendah sehingga mengalami musim panas dan Benua Asia bertekanan tinggi sehingga mengalami musim lebih dingin, sehingga angin bergerak dari Benua Asia ke Benua Australia dari tekanan tinggi ke tekanan rendah dan menghasilkan kecepatan angin yang tinggi dan mengakibatkan musim hujan. Kecepatan angin yang tinggi menghasilkan gelombang yang lebih tinggi pula (Triatmodjo, 1999).

Peramalan gelombang menggunakan metode Sugianto dipilih untuk meramalkan kondisi gelombang di Laut Jawa. Karakteristik metode Sugianto itu sendiri biasanya digunakan untuk meramalkan gelombang di Laut Jawa berdasarkan kecepatan angin dan hubungannya dengan tinggi dan periode gelombang signifikan. Sehingga apabila peramalan ini digunakan pada lokasi kajian akan menghasilkan kesalahan yang relatif kecil. Hal ini dikarenakan lokasi kajian di Perairan Pulau Panjang masih termasuk dalam Laut Jawa.

Pada hasil pemodelan spektrum gelombang menunjukkan bahwa energi gelombang yang terbentuk berada pada arah gelombang tersebut akan menjalar. Dalam CERC (1984) dinyatakan bahwa frekuensi yang terkait dengan nilai energi gelombang yang besar adalah frekuensi dominan di suatu perairan. Energi gelombang terbesar pada perairan Pulau Panjang terjadi pada musim Barat yaitu sebesar $0,33 \mathrm{~m}^{2} / \mathrm{Hz}$ dengan frekuensi $0,2 \mathrm{~Hz}$. Artinya gelombang dengan periode 5 detik akan menghasilkan nilai energi terbesar pada musim ini. Energi gelombang terkecil pada perairan Pulau Panjang terjadi pada musim Timur, yaitu sebesar $0,24 \mathrm{~m}^{2} / \mathrm{Hz}$ dengan frekuensi $0,21 \mathrm{~Hz}$. Artinya gelombang dengan periode 4,76 detik akan menghasilkan nilai energi terbesar pada musim ini. Sedangkan energi gelombang pada musim Peralihan I dan II berturut-turut adalah sebesar $0,26 \mathrm{~m}^{2} / \mathrm{Hz}$ dan $0,25 \mathrm{~m}^{2} / \mathrm{Hz}$, dengan frekuensi $0,21 \mathrm{~Hz}$ dan $0,22 \mathrm{~Hz}$. Artinya gelombang dengan periode 4,76 detik dan 4,54 detik akan menghasilkan nilai energi terbesar pada musim ini.

Berdasarkan hasil peramalan gelombang dan pemodelan spektrum gelombang tersebut, dapat diketahui tinggi gelombang dan energi gelombang laut saling berhubungan. Dimana semakin tinggi gelombang yang terbentuk maka energi yang dihasilkan juga semakin besar. Hal ini terbukti dengan tinggi gelombang terbesar yang terjadi pada musim Barat berbanding lurus dengan energi gelombang terbesar pada musim Barat. Hal ini diperkuat oleh pernyataan CERC (1984) yang menyatakan semakin besar tinggi gelombang maka nilai energi gelombang semakin besar begitu pula sebaliknya.

\section{KESIMPULAN}

Berdasarkan hasil peramalan, gelombang di Perairan Pulau Panjang relatif kecil dengan tinggi gelombang rata-rata berkisar antara 0,74-0,86 meter dan periode gelombang berkisar antara 4,74-4,93 detik. Pengolahan data angin dan pemodelan spektrum gelombang menunjukkan arah penjalaran gelombang di Perairan Pulau Panjang sesuai dengan arah angin dominannya.

Pemodelan spektrum gelombang menunjukkan energi gelombang di Perairan Pulau Panjang berkisar antara $0,24-0.34 \mathrm{~m}^{2} / \mathrm{Hz}$ dengan frekuensi dominan $0,2-0,25 \mathrm{~Hz}$.

\section{DAFTAR PUSTAKA}

Brillin, D.B., Santoso, A. dan Arief, I.S. 2015. Analisa Seakeeping pada Offshore Supply Vessel 56 Meter. Jurnal Teknik ITS, 4(2).

Coastal Engineering Research Center (CERC). 1984. Shore Protection Manual. Volume I. $4^{\text {th }}$ ed., Army Coastal Engineering Research Center, Washington, 337 p.

Holthuijsen, L.H., N. Booij and Herbers, T.H.C. 1989. A Prediction Model for Stationary, Short-crested Waves in Shallow Water with Ambient Current. Coastal Engineering, 13: 23-54. 
Malik, Abdul. 2017. Strategi Pengembangan Ekowisata Berbasis Konservasi Sumber Daya Alam Berkelanjutan di Pulau Panjang Kabupaten Jepara.

Mulyadi, Jumarang, M. I. dan Apriansyah. 2015. Studi Variabilitas Tinggi dan Periode Gelombang Laut Signifikan di Selat Karimata. POSITRON, Vol. V, No. 1 (2015), Hal. 19-25.

Satriyani. 2007. Studi Identifikai Pola Utama Data Radiosonde Melalui Analisis Komponen Utama dan Analisis Spektrum (Studi Kasus Bandung). [Skripsi]. Fakultas Matematika dan Ilmu Pengetahuan Alam, Institut Pertanian Bogor, Bogor, 34 hlm.

Sugianto, D.N., Zainuri, M., Darari, M., Suripin, S. D. dan Yuwono, N. 2017. Wave Height Forecasting Using Measurement Wind Speed Distribution Equation in Java Sea, Indonesia. International Journal of Civil Engineering and Technology (IJCIET), 8(5): 604-619.

Sugiyono. 2009. Metode Penelitian Kuantitatif Kualitatif dan R\&D. CV Alfabeta, Bandung

Triatmodjo B. 1999. Teknik Pantai. Beta Offset, Yogyakarta, 397 hlm. 